\title{
PEMBELAJARAN IPA TERPADU DENGAN PENDEKATAN PENEMUAN (DISCOVERY) MELALUI METODE DEMONSTRASI DAN EKSPERIMEN DITINJAU DARI KEMAMPUAN BERFIKIR KRITIS DAN KREATIVITAS SISWA
}

\author{
Syahrul Nur Abidin ${ }^{1}$, Sarwanto $^{2}$ dan Widha Sunarno ${ }^{3}$ \\ ${ }^{1}$ Magister Pendidikan Sains, Fakultas Keguruan dan Ilmu Pendidikan, Universitas Sebelas Maret \\ Surakarta, 57126, Indonesia \\ syahrulmaospati@gmai.com \\ ${ }^{2}$ Magister Pendidikan Sains, Fakultas Keguruan dan Ilmu Pendidikan, Universitas Sebelas Maret \\ Surakarta, 57126, Indonesia \\ sarwanto@fkip.uns.ac.id \\ ${ }^{3}$ Magister Pendidikan Sains, Fakultas Keguruan dan Ilmu Pendidikan, Universitas Sebelas Maret \\ Surakarta, 57126, Indonesia \\ widhasunarno@staff.uns.ac.id
}

\begin{abstract}
Abstrak
Tujuan penelitian ini adalah untuk mengetahui: pengaruh pendekatan penemuan melalui metode demonstrasi dan eksperimen, kemampuan berfikir kritis, kreativitas terhadap hasil belajar siswa. Penelitian ini menggunakan metode eksperimen dan dilaksanakan dari bulan Januari-Mei 2016. Populasi penelitian ini adalah semua siswa kelas VII SMP Negeri 1 Karas tahun pelajaran 2015/2016. Sampel diperoleh dengan teknik cluster random sampling yang terdiri dari dua kelas, VII-1 dan VII-2. Kelas VII-1 diberi pembelajaran dengan metode eksperimen dan kelas VII-2 diberi pembelajaran dengan metode demonstrasi. Data dikumpulkan dengan metode tes untuk hasil belajar, angket untuk kemampuan berfikir kritis dan kreativitas. Hipotesis diuji meggunakan ANAVA dengan desain faktorial $2 \times 2 \times 2$ sel tak sama dengan bantuan software SPSS versi 21.Dari hasil analisis data disimpulkan: 1) Ada perbedaan hasil belajar fisika terhadap penggunaan metode eksperimen dan metode demonstrasi, maka metode pembelajaran memberikan perbedaan yang signifikan terhadap hasil belajar, 2) Ada perbedaan hasil belajar terhadap kemampuan berpikir kritis tinggi dan kemampuan berpikir kritis rendah, yang berarti bahwa kemampuan berpikir kritis memberikan perbedaan yang signifikan terhadap hasil belajar, 3) Ada perbedaan hasil belajar terhadap kreativitas tinggi dan kreativitas rendah, yang berarti bahwa kreativitas memberikan perbedaan yang signifikan terhadap hasil belajar, 4) Tidak ada interaksi antara metode pembelajaran dengan cara berpikir kritis siswa yang berarti metode pembelajaran dan cara berpikir kritis siswa secara bersama-sama tidaklah memberikan hasil yang signifikan terhadap prestasi belajar, 5) Ada interaksi antara metode pembelajaran dengan kreativitas siswa yang berarti bahwa metode pembelajaran dan kreativitas siswa secara bersama-sama memberikan hasil yang signifikan terhadap prestasi belajar siswa, 6) Tidak ada interaksi antara cara berpikir kritis siswa dengan kreativitas siswa yang berarti cara berpikir kritis siswa dan kreativitas siswa secara bersama-sama tidaklah memberikan hasil yang signifikan terhadap prestasi belajar, 7) Ada interaksi antara metode pembelajaran, cara berpikir kritis siswa, dan kreativitas siswa yang berarti metode pembelajaran, cara berpikir kritis siswa, dan kreativitas siswa secara bersama-sama memberikan hasil yang signifikan terhadap prestasi belajar siswa.
\end{abstract}

Kata Kunci: Pendekatan Penemuan, Metode Eksperimen, Metode Demonstrasi, Kemampuan Berfikir Kritis, Kreativitas, Hasil Belajar.

Pendahuluan

Pendidikan adalah usaha sadar dan terencana untuk mewujudkan suasana belajar dan proses pembelajaran agar peserta didik secara aktif mengembangkan potensi dirinya untuk memiliki kekuatan spiritual keagamaan, pengendalian diri, kepribadian, kecerdasan, akhlak mulia, serta keterampilan yang diperlukan dirinya dan masyarakat. Masalah pendidikan adalah masalah yang sangat penting bagi manusia. Penguasaan Ilmu 
Pengetahuan dan Teknologi (IPTEK) menjadi prasyarat untuk memperoleh peluang partisipasi, adaptasi, dan sekaligus untuk meningkatkan sumber daya manusia yang berkualitas, salah satunya dapat dilakukan melalui pendidikan IPA.

Penguasaan model pembelajaran sangat tergantung pada pengalaman yang dirancang guru dalam melibatkan siswa selama pembelajaran. Guru harus bertanggung jawab terhadap proses pembelajaran mulai dari perencanaan sampai evaluasi.

Permasalahan terbesar yang dihadapi para peserta didik sekarang (siswa) adalah mereka belum bisa menghubungkan antara apa yang mereka pelajari dan bagaimana pengetahuan itu akan digunakan. Hal ini dikarenakan cara mereka memperolah informasi dan kreativitas diri belum tersentuh oleh metode yang bisa membantu mereka. Siswa kesulitan untuk memahami konsepkonsep akademis (seperti konsep-konsep matematika, fisika, atau biologi), karena metode mengajar yang selama ini digunakan oleh pendidik (guru) hanya terbatas pada metode ceramah. Di sini lain tentunya siswa tahu apa yang mereka pelajari saat ini akan sangat berguna bagi kehidupan mereka di masa datang, yaitu saat mereka bermasyarakat ataupun saat di tempat kerja kelak. Oleh karena itu diperlukan suatu metode yang benar-benar bisa memberi jawaban dari masalah ini. Salah satu metode yang bisa lebih memberdayakan siswa dalah pendekatan Discovery Learning (Penemuan).

Penemuan (discovery) merupakan suatu model pembelajaran yang dikembangkan berdasarkan perkembangan kontruktivisme. Model ini menekankan pentingnya pemahaman struktur atau ide-ide penting terhadap suatu disiplin ilmu, melalui keterlibatan siswa aktif dalam proses pembelajaran.

Pendekatan Discovery melalui metode demonstrasi dan eksperimen lebih berpusat pada siswa dan memberi kesempatan kepada siswa untuk terlibat langsung dalam proses pengamatan maupun penggunaan alat dan bahan. Demonstrasi maupun eksperimen, siswa tetap menjadi pusat pembelajaran dengan bimbingan guru. Perbedaan kedua metode adalah dari segi alat praktikum, demontrasi menggunakan fasilitas guru yang mendemonstrasikan praktikum, sedangkan eksperimen menggunakan alat praktikum untuk setiap kelompok.

Pada penerapan proses pembelajaran IPA di kelas, umumnya para guru masih cenderung berkonsentrasi pada latihan penyelesaian soal yang bersifat prosedural. Seperti dinyatakan oleh Silver (Turmudi, 2009) bahwa pada pembelajaran tradisional, aktivitas siswa sehari-hari umumnya menonton gurunya menyelesaikan soal-soal di papan tulis kemudian meminta siswa bekerja sendiri dalam buku teks atau lembar kerja siswa (LKS) yang disediakan. Menurut Sumarmo (2000), untuk dapat mengembangkan kemampuan berpikir matematis dalam pembelajaran, guru juga perlu mendorong siswa untuk terlibat aktif dalam diskusi, bertanya serta menjawab pertanyaan, berpikir secara kritis, menjelaskan setiap jawaban yang diberikan, serta mengajukan alasan untuk setiap jawaban yang diajukan.

Untuk menangani permasalahanpermasalahan yang dihadapi guru harus lebih kreatif dalam menyampaikan materi, baik dari penguasaan materi, model pembelajaran yang tepat, dan pemanfaat sarana dan prasarana yang menunjang untuk meningkatakan proses pembelajaran IPA. Dengan kemampuan dan kreativitas dari guru dalam penggunaan model pembelajaran, dan metode pembelajaran akan memudahkan siswa untuk memahami konsepkonsep IPA dengan menghubungkan antara kemampuan yang dimiliki siswa dan menerapkannya dalam kehidupan sehari-hari sesuai dengan tujuan pembelajaran. Sehingga kemampuan guru dalam menggunakan modelmodel pembelajaran serta penggunaan metode pembelajaran akan meningkatkan kemampuan siswa dalam memahami dan menguasai konsep IPA secara sungguh-sungguh.

Kebanyakan pengajar, khususnya guru IPA hanya menilai apa yang diketahui siswa dan belum menilai apa yang dapat dilakukan siswa. Guru cenderung memfokuskan pada soal-soal ujian bukan pada menjadikan siswa lebih berperan aktif dalam proses 
pembelajaran. Seorang guru harus mempunyai strategi-strategi pembelajaran yang mampu meningkatkan hasil belajar siswa. Siswa haruslah dikreativitas pada sesuatu hal yang baru, dan bisa menarik perhatian, salah satunya adalah dengan menggunakan metode-metode pembelajaran yang menarik dan mencontohkan bentuk fakta dari materi yang menjadikan pembelajaran dikelas bisa menjadi "learning is fun".

Dari beberapa permasalahan tersebut maka diperlukan suatu cara untuk memecahkannya, yaitu dengan menerapkan suatu metode baru dalam proses belajar mengajar. Berdasarkan uraian tersebut peneliti mencoba menerapkan pendekatan penemuan. Metode pembelajaran ini mengkondisikan siswa untuk dapat lebih terkreativitas dan terbiasa aktif dalam pembelajaran, yang kemudian akan meningkatkan hasil belajar siswa dan dapat mencapai standar ketuntasan belajar yang telah ditentukan.

Sesuai dengan pembahasan yang sudah di sajikan di depan maka dilakukan penelitian dengan judul "Pembelajaran IPA Terpadu Dengan Model Penemuan (Discovery) Melalui Metode Demonstrasi Dan Eksperimen Ditinjau Dari Berpikir Kritis Dan Kreativitas Siswa".

Dalam penelitian ini bertujuan untuk mengetahui

a. Pengaruh pendekatan penemuan melalui metode demonstrasi dan eksperimen terhadap hasil belajar IPA

b. Pengaruh berpikir kritis terhadap hasil belajar

c. Pengaruh kreativitas siswa terhadap hasil belajar

d. Interaksi antara pendekatan penemuan dan berpikir kritis terhadap hasil belajar

e. Interaksi antara pendekatan penemuan terhadap kreativitas siswa

f. Interaksi antara berpikir kritis dan kreativitas siswa terhadap hasil belajar

g. Interaksi antara pendekatan penemuan dengan berpikir kritis dan kreativitas siswa terhadap hasil belajar

\section{Metode Penelitian}

Sebagai populasi dalam penelitian ini adalah siswa SMPN 1 Karas tahun pelajaran 2015/2016. Teknik pengambilan sampel dilakukan adalah cluster random samplig.

Teknik pengumpulan data adalah suatu cara untuk mengumpulkan data yang diperlukan dalam penelitian. Data tersebut bisa diperoleh dari evaluasi hasil belajar. Metode yang digunakan adalah metode tes dan metode angket.

a. Instrumen Penelitian

a. Instrumen Pembelajaran

1). Silabus Pembelajaran

2). Rencana Pelaksanaan Pembelajaran (RPP)

b. Instrumen Penelitian

1) Tes

Melalui metode tes ini akan diperoleh data yang berupa hasil belajar siswa berupa nilai prestasi siswa. Arikunto (2002: 127) menyebutkan, bahwa "Tes adalah serentetan pertanyaan atau latihan atau alat lain yang digunakan untuk mengukur ketrampilan, pengetahuan intelegensi, kemampuan atau bakat yang dimiliki individu atau kelompok".

Metode tes digunakan untuk memperoleh data hasil belajar siswa yang diajar dengan Metode Demonstrasi dan metode Eksperimen. Tes yang digunakan adalah tes tertulis berbentuk tes pilihan ganda dengan jumlah soal 25 butir soal.

2) Angket

Angket merupakan teknik pengumpulan data yang dilakukan dengan cara memberi seperangkat pertanyaan kepada responden untuk dijawabnya Sugiyono (2008: 199). Angket dalam penelitian ini digunakan untuk mengukur motivasi belajar siswa. Angket yang digunakan memuat pertanyaan tentang motivasi belajar fisika siswa berupa pilihan ganda dengan 4 alternatif.

\section{Analisis Data}

Analisis data merupakan tahapan penelitian yang akan menguji kebenaran hipotesis yang diajukan. Untuk mencapai tujuan penelitian digunakan angka-angka statistik dan tabel dengan maksud untuk memudahkan peneliti dalam mencari 
kebenaran proses analisis data. Metode analisis data meliputi:

a. Uji Validitas Soal Dan Lembar Angket

Validitas adalah suatu ukuran yang menunjukkan tingkat-tingkat kevalidan atau kesahihan suatu instrumen. Suatu instrumen yang valid atau sahih mempunyai validitas tinggi. Sebaliknya, instrumen yang kurang valid berarti memiliki validitas rendah. Suharsimi Arikunto (2007: 72)

1. Uji Reliabilitas Soal Dan Lembar Angket

Reliabilitas menunjukkan pada satu pengertian bahwa suatu instrumen cukup dapat dipercaya untuk dipergunakan sebagai alat pengumpul data (Suharsimi Arikunto, 2006: 178). Untuk menghitung reliabilitas butir soal digunakan rumus belah dua awal dan akhir. Reliabilitas soal dapat dicari setelah mengetahui validitas butir soal $r_{x y}\left(r_{\frac{1}{2}}\right)$ maka reliabilitas tes dapat dicari dengan menggunakan rumus Spearman-Brown:

$$
r_{11}=\frac{2 \cdot r_{\frac{1}{2} \frac{1}{2}}}{\left(1+r_{\frac{11}{2} \frac{1}{2}}\right)}
$$

Dimana :

$r_{11}=$ korelasi antar skor-skor tiap belahan tes.

$$
r_{\frac{11}{22}}=\text { koefisien reliabilitas. }
$$

Suharsimi Arikunto (2007: 93)

Kriteria reliabilitas ditetapkan sebagai berikut:

Jika $r_{\text {hitung }}>r_{\text {tabel }}$, maka soal tes dinyatakan reliabel

Jika $r_{\text {hitumg }}<r_{\text {tabel }}$ maka soal tes dinyatakan tidak reliabel

\section{Uji Normalitas}

Uji normalitas yang digunakan adalah uji normalitas metode Kolmogorov-Smirnov karena datanya tidak dalam distribusi frekuensi data bergolong. Menurut Tri Cahyono (2006: 17) mengatakan, pada metode KolmogorovSmirnov setiap data $x_{\tilde{i}}$ diubah menjadi bilangan baku $z_{i}$ dengan transformasi:

$$
z_{i}=\frac{x_{i}-\bar{x}}{s} \text { dengan } s \text { dicari dari }
$$

rumus

$$
s=\sqrt{\frac{n\left(\sum x^{2}\right)-\left(\sum x\right)^{2}}{n(n-1)}}
$$

(Tri Cahyono, 2006: 17)

Keterangan:

$s=$ standar deviasi

$\bar{x}=$ mean sampel

$z=$ variabel unit standar

Langkah-langkah uji normalitas dengan metode Kolmogorov-Smirnov adalah sebagai berikut.

a. $H_{0}$ : sampel berasal dari populasi yang berdistribusi normal

$H_{1}$ : sampel tidak berasal dari populasi berdistribusi normal

b. Tingkat signifikan $\alpha=0,05$

c. Statistik uji yang digunakan adalah: Nilai maksimal $\left\|F_{T}-F_{S}\right\|$

d. Daerah penolakan. $\left|F_{T}-F_{S}\right|<\mid$ tabel $\mid ;$ berarti $H_{0}$ diterima dan $H_{1}$ ditolak.

(Tri Cahyono,2006: 17)

\section{Uji homogenitas}

Uji homogenitas digunakan untuk mengetahui apakah dua sampel mempunyai varian yang sama atau homogen.

Langkah-langkah yang ditempuh:

a. Menentukan hipotesis

$H_{0}=\sigma_{1}^{2} \leq \sigma_{2}^{2}=$ varian sama

$H_{1}=\sigma_{1}^{2}>\sigma_{2}^{2}=$ varian tidak sama

b. Menentukan taraf signifikan $\alpha$.

c. Menghitung nilai $\mathrm{F}$ dengan rumus:

$$
F=\frac{\text { Varians terbesar }}{\text { Varians terkecil }}
$$

d. Menentukan criteria pengujian

$$
\begin{aligned}
& H_{0} \text { diterima jika } F \leq F_{\text {tabel }} \\
& H_{0} \text { ditolak jika } F>F_{\text {tabel }}
\end{aligned}
$$

4. Uji hipotesis

Dalam penelitian ini menggunakan analisis variansi (anava) tiga jalan dengan sel tak sama. 
Langkah-langkah yang ditempuh:

a. Menentukan hipotesis

1. Hipotesis $\mathrm{Nol}\left(H_{0}\right)$

$H_{01}$ : tidak ada perbedaan metode pembelajaran melalui metode eksperimen dan diskusi terhadap prestasi belajar siswa.

$H_{02}$ : tidak ada perbedaan kemampuan berpikir kritis tinggi dan kemampuan berpikir kritis rendah terhadap prestasi belajar siswa.

$H_{03}$ : tidak ada perbedaan kemampuan kreatifitas tinggi dan kemampuan kreatifitas rendah terhadap prestasi belajar siswa.

$H_{012}$ : tidak ada interaksi antara metode pembelajaran dengan kemampuan berpikir kritis terhadap prestasi belajar siswa.

$H_{013}$ : tidak ada interaksi antara metode pembelajaran dengan kreatifitas terhadap prestasi belajar siswa.

$H_{023}$ : tidak ada interaksi antara kemampuan berpikir kritis dengan kreatifitas terhadap prestasi belajar siswa.

$H_{0123}$ : tidak ada interaksi antara metode pembelajaran dengan kemampuan berpikir kritis dan kreatifitas terhadap prestasi belajar siswa.

2. Hipotesis Alternatif $\left(H_{1}\right)$

$$
\begin{aligned}
H_{11} & : \text { ada perbedaan metode } \\
& \text { pembelajaran melalui metode } \\
& \text { eksperimen dan diskusi } \\
& \text { terhadap prestasi belajar siswa. } \\
H_{12}: \text { ada perbedaan kemampuan } & \text { berpikir kritis tinggi dan } \\
& \text { kemampuan berpikir kritis } \\
& \text { rendah terhadap prestasi } \\
& \text { belajar siswa. } \\
H_{13}: \text { ada perbedaan kemampuan } & \text { kreatifitas tinggi dan } \\
& \text { kemampuan kreatifitas rendah } \\
& \text { terhadap prestasi belajar siswa. } \\
H_{112} & \text { ada interaksi antara metode } \\
& \text { pembelajaran dengan }
\end{aligned}
$$

kemampuan berpikir kritis terhadap prestasi belajar siswa.

$H_{113}$ : ada interaksi antara metode pembelajaran dengan kreatifitas terhadap prestasi belajar siswa.

$H_{123}$ : ada interaksi antara kemampuan berpikir kritis dengan kreatifitas terhadap prestasi belajar siswa.

$H_{1123}$ : ada interaksi antara metode pembelajaran dengan kemampuan berpikir kritis dan kreatifitas terhadap prestasi belajar siswa.

b. Menentukan statistik uji

Uji hipotesis dalam penelitian ini menggunakan Analisis Varian (Anava) tiga jalan dengan General Linier Model (GLM) yang perhitungan dilakukan dengan SPSS 17. Adapun cara manualnya sebagai berikut:

1. Menentukan hipotesis.

2. Menentukan rataan harmonik frekuensi seluruh sel dengan $n_{i}=\frac{p q r}{\sum_{i j k_{m_{i j k}}}}$

3. Menentukan banyaknya seluruh data $\operatorname{amatan}(\mathrm{N})$.

4. Mendefinisikan besaran-besaran sebagai berikut:

1) $\frac{G^{2}}{N}$

2) $\sum_{i, j, j, k i l} X_{i j k l}^{2}$

3) $\sum_{i} \frac{A_{i}^{2}}{\text { ngr }}$

4) $\sum_{j} \frac{B_{j}^{2}}{n p r}$

5) $\sum_{k} \frac{c_{k}^{2}}{\text { прq }}$

6) $\sum_{i j} \frac{A B_{i j}^{2}}{n r^{2}}$

7) $\sum_{i k} \frac{A C_{i k}^{2}}{n q}$

8) $\sum_{j k} \frac{B C_{j k}^{2}}{n p}$

9) $\sum_{i, j, k} \frac{B C_{i, k}^{2}}{n}$

5. Menentukan jumlah kuadrat pada analisis wariansi tiga jalan berikut ini: 
$\mathrm{JKA}=3-1 ; \mathrm{JKB}=4-1 ; \mathrm{JKC}=5-1 ;$

$\mathrm{JKAB}=(1+6-3-4) ; \mathrm{JKAC}=1+7-3-5$;

$\mathrm{JKBC}=1+8-4-5 ; \mathrm{JKABC}=3+4+5+9-$ $1-6-7-8 ; \mathrm{JKG}=2-9$;

$\mathrm{JKT} \quad=\quad 2-1$ atau

$(\mathrm{JKA}+\mathrm{JKB}+\mathrm{JKC}+\mathrm{JKAB}+\mathrm{JKAC}+\mathrm{JKB}$

$\mathrm{C}+\mathrm{JKABC}+\mathrm{JKG})$

6. Menentukan derajat kebebasan untuk masing-masing jumlah kuadrat tersebut adalah:

$\mathrm{dkA}=\mathrm{p}-1 ; \mathrm{dkB}=\mathrm{q}-1 ; \mathrm{dkC}=\mathrm{r}-1 ;$ $\mathrm{dkAB}=(\mathrm{p}-1)(\mathrm{q}-1) ; \mathrm{dkAC}=(\mathrm{p}-1)(\mathrm{r}-1) ;$ $\mathrm{dkBC}=(\mathrm{q}-1)(\mathrm{r}-1) ; \mathrm{dkABC}=(\mathrm{p}-1)(\mathrm{q}-$ 1)(r-1); dkG = N-pqr; dkT = N-1

7. Berdasarkan jumlah kuadrat dan derajat kebebasan masing-masing, diperoleh rataan kuadrat berikut :

f. Untuk $H_{0 B C}$ adalah $F_{a}=\frac{R K B C}{R K G}$ yang merupakan nilai dari variable random yang berdistribusi $\mathrm{F}$ dengan derajat kebebasan $(\mathrm{q}-1)(\mathrm{r}-1)$ dan $\mathrm{N}-$ pqr.

g. Untuk $H_{0 A B C}$ adalah $F_{a}=\frac{R K A B C}{R K G}$ yang merupakan nilai dari variable random yang berdistribusi $\mathrm{F}$ dengan derajat kebebasan $(\mathrm{p}-1)(\mathrm{q}-1)(\mathrm{r}-1)$ dan N-pqr.

c. Menentukan taraf signifikan $(\alpha)$

Taraf signifikansi merupakan angka yang menunjukkan seberapa besar peluang terjadinya kesalahan analisis. Pada uji hipotesis ini, taraf signifikan $(\alpha)$ yang digunakan adalah 0,05 atau $5 \%$.

$R K A=\frac{J K A}{d k A} ; R K B=\frac{J K B}{d k B} ; R K C=\frac{J K C}{d k C} ;$

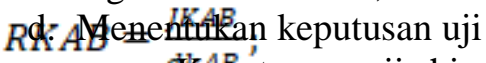

Kepuutusan uji hipotesis ditentukan

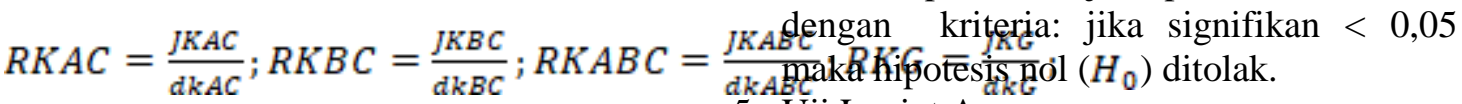

5. Uji Lanjut Anava

8. $\quad$ Statistik uji

Statistik uji yang digunakan adalah:

a. Untuk $H_{0 A}$ adalah $F_{a}=\frac{R K A}{R K f}$ yang merupakan nilai dari variable random yang berdistribusi $\mathrm{F}$ dengan derajat kebebasan p-1 dan N-pqr.

b. Untuk $H_{0 B}$ adalah $F_{b}=\frac{R K B}{R K G}$ yang merupakan nilai dari variable random yang berdistribusi $\mathrm{F}$ dengan derajat kebebasan q-1 dan N-pqr.

c. Untuk $H_{O C}$ adalah $F_{\mathrm{a}}=\frac{R K C}{R K G}$ yang merupakan nilai dari variable random yang berdistribusi $\mathrm{F}$ dengan derajat kebebasan r-1 dan N-pqr.

d. Untuk $H_{0 A B}$ adalah $F_{a}=\frac{R K A B}{R K f}$ yang merupakan nilai dari variable random yang berdistribusi $F$ dengan derajat kebebasan $(\mathrm{p}-1)(\mathrm{q}-1)$ dan Npqr.

e. Untuk $H_{0 A C}$ adalah $F_{a}=\frac{R K A C}{R K G}$ yang merupakan nilai dari variable random yang berdistribusi $F$ dengan derajat kebebasan $(\mathrm{p}-1)(\mathrm{r}-1)$ dan $\mathrm{N}-$ pqr.
Uji lanjut Anava merupakan tindak lanjut dari analisis variasi, apabila hasil analisis variasi menunjukkan bahwa hipotesis nol ditolak. Tujuan dari uji lanjut anava ini adalah untuk melakukan pengacakan terhadap rerata setiap pasangan kolom, baris, dan pasangan sel sehingga diketahui pada bagian mana sajakah terdapat rerata yang berbeda.

Dalam penelitian ini digunakan uji lanjut anava metode Komparansi Ganda dengan Uji Scheffe. Langkah-langkahnya yaitu sebagai berikut:

a. Mengidentifikasi semua pasangan komparansi rataan yang ada. Jika terdapat perlakuan, maka ada $\frac{k(k-1)}{2}$ pasangan rataan.

b. Merumuskan hipotesis yang bersesuaian dengan komparansi tersebut.

c. Menentukan tingkat signifikansi $\alpha$

d. Mencari statistik uji Fdengan menggunakan rumus sebagai berikut:

1. Komparansi rataan antar baris

$$
F_{i-j}=\frac{\left(\bar{M}_{i}-\bar{M}\right)^{2}}{M S \operatorname{Mer}\left[\frac{1}{n_{i}}+\frac{1}{m_{i}}\right]}
$$

2. Komparansi rataan antar kolom 


$$
F_{i-j}=\frac{\left(\overline{N_{i}}-\bar{M}\right)^{2}}{M S_{e r r}\left[\frac{1}{n_{i}}+\frac{1}{m_{i}}\right]}
$$

3. Komparansi rataan antar sel pada kolom yang sama

$$
F_{i j-i k}=\frac{\left(\overline{X_{i j}}-\overline{X_{i k}}\right)^{2}}{M S_{e r r}\left[\frac{1}{n i j}+\frac{1}{m_{i k}}\right]}
$$

4. Komparansi rataan antar sel pada baris yang sama

$$
F_{i j-k j}=\frac{\left(\bar{M}_{i j}-\overline{X_{k j}}\right)^{2}}{M S_{e r r}\left[\frac{1}{n_{i j} j}+\frac{1}{n_{k j}}\right]}
$$

e. Menentukan daerah kritik dengan minus sebagai berikut:

1. Komparansi rataan antar baris

$$
D K_{i-i}=F_{i-i} \geq(p-1) F_{\propto_{i} p-1 ; i n-p q}
$$

2. Komparansi rataan antar kolom

$$
D K_{i-i}=F_{i-i} \geq(q-1) F_{0 c_{i p}-1 ; N-p q}
$$

3. Komparansi rataan antar sel pada kolom yang sama

$$
D K_{i j-k j}=F_{i j-k j} \geq(p q-1) F_{\propto i p q-1 i j} N-p q
$$

4. Komparansi rataan antar sel pada baris yang sama

$$
D K_{i j-i k}=F_{i j-i k} \geq(p q-1) F_{\propto p}(p-1)(q-1) ; N-p
$$

f. Menentukan keputusan uji.

g. Menentukan kesimpulan dan keputusan uji yang ada.

\section{Hasil Penelitian dan Pembahasan}

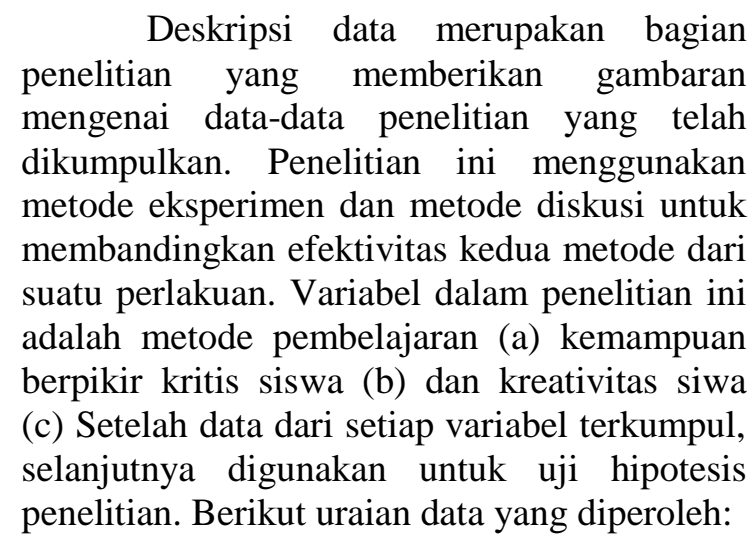

1. Data Berpikir Kritis Siswa

Dalam penelitian ini data kemampuan berpikir kritis diperoleh dari pemberian angket kemampuan berpikir kritis kepada responden. Pembagian kategori kemampuan berpikir kritis tinggi dan kemampuan berpikir kritis rendah berdasarkan rata-ratanya. Kemampuan berpikir kritis tinggi jika skornya $=$ rata-

\begin{tabular}{|c|c|c|c|c|}
\hline \multirow[b]{2}{*}{$\begin{array}{c}\text { Berpi- } \\
\text { kir } \\
\text { Kritis }\end{array}$} & \multicolumn{2}{|c|}{ Metode Eksperimen } & \multicolumn{2}{|c|}{ Metode Diskusi } \\
\hline & Frekuensi & Prosentase & $\begin{array}{c}\text { Frekuen } \\
\text { si }\end{array}$ & $\begin{array}{c}\text { Pro- } \\
\text { senta } \\
\text {-se }\end{array}$ \\
\hline Tinggi & 13 & 43,3 & 16 & 53,3 \\
\hline Rendah & 17 & 56,7 & 14 & 46,7 \\
\hline Total & 30 & 100 & 30 & 100 \\
\hline
\end{tabular}
rata dan kemampuan berpikir kritis rendah jika skornya < rata-rata ditunjukan tabel 4.1 dibawah. Adapun hasil selengkapnya dapat dilihat pada lampiran

Tabel 4.11 variabel moderator kemampuan berpikir kritis siswa

2. Data Kreativitas Siswa

Dalam penelitian ini data kreativitas siswa diperoleh dari pemberian angket kreativitas siswa kepada responden. Pembagian katagori kreativitas siswa tinggi dan kreativitas siswa rendah berdasarkan rata-ratanya

\begin{tabular}{|c|c|c|c|c|}
\hline \multirow[b]{2}{*}{$\begin{array}{c}\text { Kreativit } \\
\quad \text { as }\end{array}$} & \multicolumn{2}{|c|}{ Metode Eksperimen } & \multicolumn{2}{|c|}{ Metode Diskusi } \\
\hline & $\begin{array}{c}\text { Frekuen } \\
\text { si }\end{array}$ & $\begin{array}{c}\text { Prosenta } \\
\text { se }\end{array}$ & $\begin{array}{c}\text { Frekuen } \\
\text { si }\end{array}$ & $\begin{array}{c}\text { Prosenta } \\
\text { se }\end{array}$ \\
\hline Tinggi & 12 & 40 & 12 & 40 \\
\hline Rendah & 18 & 60 & 18 & 60 \\
\hline Total & 30 & 100 & 30 & 100 \\
\hline
\end{tabular}
kreativitas siswa tinggi jika skornya $=$ Fata-rata dan kreativitas siswa rendah jika skornya < rata-rata data ditunjukan pada tabel. Adapun hasil selengkapnya dapat dilihat pada lampiran

Tabel 4.12 variabel moderator kreativitas siswa

3. Data Prestasi Belajar Siswa

Perbandingan prestasi belajar siswa pada materi suhu dan pemuaian antara kelas eksperimen menggunakan metode pembelajaran eksperimen dan metode diskusi diperlihatkan pada tabel dibawah ini. Adapun hasil selengkapnya dapat dilihat pada lampiran 


\begin{tabular}{lllll} 
Kelompok & $\begin{array}{c}\text { Tabel 4.13 data hasilbelajar } \\
\text { Jumlah }\end{array}$ & Maksimal & Minimal & $\begin{array}{c}\text { Rata- } \\
\text { Siswa }\end{array}$ \\
& & 100 & 68 & 89,1 \\
\hline Metode & 30 & 100 & 64 & 83,6 \\
$\begin{array}{l}\text { Eksperimen } \\
\text { Metode }\end{array}$ & 30 & & & \\
Diskusi & & & & \\
\hline
\end{tabular}

Dasar pengambilan keputusan berdasarkan probabilitas: apabila probabilitas $>0,05$; maka Ho diterima, dan apabila probabilitas < 0,05; maka Ho ditolak. Pada tabel Analysis of Variance for Prestasi, using Adjusted SS for Tests memperlihatkan penyajian ANOVA lebih dari satu keragaman untuk menguji perbedaan dan pengaruh Metodel Pembelajaran, Berpikir Kritis Siswa dan Kreativitas siswa terhadap Prestasi Belajar, dengan dasar pengujian nilai $\mathrm{F}$.

\section{a. Uji No: 1}

Uji pengaruh pembelajaran dengan metode eksperimen dan metode diskusi terhadap prestasi belajar Fisika: nilai $\mathrm{F}$ hitung $=5,32$ dengan probabilitas $(\mathrm{p})=0,025$. Oleh karena $\mathrm{p}<0,05$; maka Ho ditolak, atau Metode Pembelajaran melalui eksperimen dan diskusi memberikan pengaruh signifikan terhadap prestasi belajar atau ada perbedaan antara metode pembelajaran eksperimen dan diskusi terhadap prestasi belajar.

b. Uji No: 2

Uji pengaruh sikap berpikir kritis siswa terhadap prestasi belajar siswa: nilai $\mathrm{F}$ hitung $=16,96$ dengan probabilitas $(\mathrm{p})=$ 0.01. Oleh karena $\mathrm{p}<0,05$; maka Ho ditolak, atau sikap berpikir kritis siswa memberikan pengaruh signifikan terhadap prestasi belajar atau ada perbedaan antara sikap berpikir kritis siswa tinggi dan rendah terhadap prestasi belajar.

c. Uji No: 3

Uji pengaruh kreativitas siswa terhadap prestasi belajar siswa: nilai $\mathrm{F}$ hitung $=5,01$ dengan probabilitas $(\mathrm{p})=0,03$. Oleh karena $\mathrm{p}<0,05$; maka Ho ditolak, atau kreativitas siswa memberikan pengaruh signifikan terhadap prestasi belajar atau ada perbedaan antara kreativitas siswa tinggi dan rendah terhadap prestasi belajar.

d. Uji No: 4

Uji interaksi pengaruh metode pembelajaran dan sikap berpikir kritis siswa terhadap prestasi belajar siswa: nilai $\mathrm{F}$ hitung $=0,843$ dengan probabilitas $(\mathrm{p})=$ 0,363 . Oleh karena $\mathrm{p}>0,05$; maka Ho diterima, atau interaksi antara metode pembelajaran dengan sikap berpikir kritis siswa tidak memberikan pengaruh signifikan terhadap prestasi belajar.

e. Uji No: 5

Uji interaksi pengaruh metode pembelajaran dan kreativitas siswa terhadap prestasi belajar siswa: nilai $\mathrm{F}$ hitung $=4,124$ dengan probabilitas $(p)=0,047$. Oleh karena $\mathrm{p}<0,05$; maka Ho ditolak, atau interaksi antara metode pembelajaran dengan kreativitas siswa memberikan pengaruh signifikan terhadap prestasi belajar.

\section{f. Uji No: 6}

Uji interaksi pengaruh berpikir kritis siswa dan kreativitas siswa terhadap prestasi belajar siswa: nilai $\mathrm{F}$ hitung $=0,24$ dengan probabilitas $(p)=0,62$. Oleh karena $p>0,05$; maka Ho diterima, atau interaksi antara berpikir kritis dan kreativitas siswa tidak memberikan pengaruh signifikan terhadap prestasi belajar.

g. Uji No: 7

Uji pengaruh interaksi metode pembelajaran, berpikir kritis dan kreativitas siswa: nilai $\mathrm{F}$ hitung $=4,129$ dengan probabilitas $(\mathrm{p})=0,047$ Oleh karena $\mathrm{p}<$ 0,05; maka Ho ditolak, atau interaksi metode pembelajaran, berpikir kritis, dan kreativitas siswa memberikan pengaruh signifikan terhadap prestasi belajar.

1. Uji Lanjut

Uji kelanjutan dilakukan untuk mengetahui sejauh mana interaksi kemampuan berpikir kritis dengan kreativitas siswa (mana yang berbeda dan mana yang tidak). Hal ini dapat dilakukan bila nilai $F$ hasil perhitungan menunjukkan ada perbedaan (signifikan). Sedangkan apabila nilai $\mathrm{F}$ menunjukkan tidak terdapat perbedaan uji kelanjutan ini tidak perlu dilakukan.

\section{Pembahasan}

1. Hipotesis Kesatu 
Berdasarkan penjabaran pada diskripsi statistik uji perbedaan metode pembelajaran: nilai $\mathrm{F}$ hitung $=5,324$ dengan probabilitas $(\mathrm{p})=0,025$. Oleh karena $\mathrm{p}<0,05$; maka Ho ditolak, atau metode pembelajaran memberikan perbedaan signifikan terhadap prestasi belajar atau ada perbedaan antara metode pembelajaran eksperimen dan metode pembelajaran demonstrasi terhadap prestasi belajar. Menurut rerata dari hasil analisis menunjukkan bahwa pembelajaran dengan metode eksperimen lebih unggul dari pada metode demonstrasi

Hal ini disebabkan adanya beberapa faktor antara lain: 1) pembelajaran melalui eksperimen anak lebih terarah dan terstuktur dalam melakukan percobaan yang dipandu oleh lembar kegiatan siswa yang berisi pertanyaan-pertanyaan untuk mengambil kesimpulan yang dibimbing oleh guru; 2) proses pembelajaran memberi keleluasaan pada siswa untuk melakukan percobaan dan mengeluarkan pendapat sendiri dalam rangka untuk mendapatkan konsep suhu dan pemuaian; 3) pembelajaran lebih bermakna. Sedangkan pembelajaran dengan metode demonstrasi: 1) anak hanya diberi lembar kegiatan yang kurang tersruktur dibandingkan eksperimen; 2) anak melakukan percobaan sendiri sesuai dengan petunjuk pada lembar kerja siswa sehingga anak kurang leluasa dalam menemukan kesimpulan; 3) tujuan dalam percobaan siswa hanya membuktikan teori yang sudah ada sehingga konsepkonsep yang didapatkan kurang bermakna.

2. Hipotesis Kedua

Berdasarkan penjabaran pada diskripsi statistik uji perbedaan berpikir kritis siswa: Pada tabel uji pengaruh berpikir kritis siswa terhadap prestasi belajar siswa: nilai $\mathrm{F}$ hitung $=16,960$ dengan probabilitas $(p)=0.000$. Oleh karena $\mathrm{p}<0,05$; maka Ho ditolak, atau berpikir kritis siswa memberikan belajar yang lebih tinggi dibanding dengan siswa yang memiliki berpikir kritis siswa rendah. Pengaruh signifikan terhadap prestasi belajar atau ada perbedaan antara berpikir kritis siswa tinggi dan rendah terhadap prestasi belajar. Dari rerata data tersebut dapat dilihat bahwa, secara keseluruhan dapat dijelaskan bahwa siswa yang memiliki berpikir kritis tinggi mendapatkan prestasi belajar lebih tinggi dari pada siswa yang memiliki berpikir kritis rendah. Siswa yang mempunyai sikap berpikir kritis tinggi punya kecenderungan antara lain: a) Kemampuan mengidentifikasi; b) Kemampuan mengevaluasi; c) Kemampuan menyimpulkan; d) Kemampuan mengemukakan pendapat; Hal inilah yang menyebabkan siswa yang mempunyai sikap berpikir kritis tinggi akan lebih baik dari pada siswa yang mempunyai sikap berpikir kritis rendah.

Peserta didik yang memiliki kemampuan berpikir kritis tinggi akan lebih semangat dalam belajar, mereka selalu ingin mencari tahu jawaban dari permasalahan yang mereka temui saat belajar, selalu termotivasi untuk membuktikan sesuatu atau konsep yang mereka peroleh atau pelajari. Hal ini dapat dilihat pada saat melakukan percobaan, peserta didik yang memlik kemampuan berpikir kritis tinggi akan lebih serius dalam melakukan percobaan, memiliki rasa ingin tahu yang besar, bertanggung jawab dalam kelompok nya, teliti dan jujur dalam pengambilan data, dan menghargai pendapat teman-temanya (Wade dalam Achmad, 2007). Sedangkan peserta didik yang memiliki kempuan berpikir kritis rendah, cenderung tidak percayaya diri dalam belajar dan pasif dalam melakukan percobaan atau penyelidikan. Mereka tidak memiliki sikap terbuka terhadap sumber-sumber terbaru, sulit untuk menerima adanya perbedaan, tidak teliti, argumen yang disampaikan tidak didasari oleh data-data yang akurat, dan tidak mampu membuat kesimpulan dengan tepat dari beberapa pernyataan yang ada selama proses 
pembelajaran. Sehingga hasil prestasi belajar yang mereka peroleh juga rendah.

Pemikiran kritis melibatkan penalaran secara logis, mengevaluasi apa yang tertulis atau lisan, yang mencerminkan pemikiran dan gagasan individu, dan penalaran sebagai pertanyaan diajukan untuk mengklarifikasi pemahaman. Tujuan utama eksekutif dalam sebuah organisasi harus memberikan kesempatan bagi manajemen untuk mendorong kemampuan berpikir selama diskusi dan dialog, terutama dalam waktu pengambilan keputusan seperti pertemuan atau dalam komunikasi konferensi. Pemikiran kritis mengikuti jalan, yang membawa para eksekutif dan karyawan menuju pengambilan keputusan penting yang efektif, karena memungkinkan otak menerima, menolak atau menunda penilaian untuk mencapai keputusan akhir.

3. Hipotesis Ketiga

Berdasarkan penjabaran pada diskripsi statistik uji perbedaan kreativitas siswa: nilai $\mathrm{F}$ hitung $=5,001$ dengan probabilitas $(\mathrm{p})=0,030$. Oleh karena $\mathrm{p}<$ 0,05; maka Ho ditolak, atau kreativitas siswa memberikan pengaruh signifikan terhadap prestasi belajar. Melihat rerata hasil analisis kreativitas tinggi dan rendah berpengaruh terhadap prestasi belajar. Siswa yang mempunyai sikap kreativitas tinggi punya kecenderungan antara lain: a) Sangat suka berimajinasi; b) Selalu ingin tahu; c) Memiliki pertanyaanpertanyaan besar; d) Mencari pengalaman baru.

Kreativitas dalam penelitian ini adalah kemampuan untuk membuat kombinasi-kombinasi baru, atau melihat hubungan-hubungan baru antar unsur, data, atau hal-hal yang sudah ada sebelumnya. Menurut Parnes dalam Lia Anggraeni (2013:121), bahwa kemampuan kreatifitas dapat dibangkitkan melalui masalah yang memacu pada lima macam perilaku kreatif, yaitu; 1) Fluency (kelancaran), yaitu kemampuan mengemukakan ide-ide yang srupa untuk memecahkan suatu masalah; 2) Flexcibility (keluwesan), yaitu kemampuan untuk menghasilkan berbagai macam ide guna memecahkan suatu masalah diluat kategori yang biasa; 3) Originally (keaslian), yaitu kemampuan memberikan respon yang unik dan luar biasa; 4) Elaboration (keterperincian), yaitu kemampuan menyatakan pengarahan ide secara terperinci untuk mewujudkan ide menjadi kenyataan; 5) Sensitivity (kepekaan), yaitu kepekaan menangkap dan menghasilkan masalah sebagai tanggapan terhadap suatu situasi. Oleh karena itu peserta didik yang memiliki kreativitas tinggi akan cenderung memiliki kapasitas kepahaman, sensitivitas, dan apresiasi penyelesaian masalah yang lebih baik dari pada peserta didik yang memiliki kreativitas rendah.

4. Hipotesis Keempat

Berdasarkan penjabaran pada diskripsi statistik uji interaksi metode pembelajaran dengan berpikir kritis: Pada tabel uji interaksi pengaruh metode pembelajaran dan berpikir kritis siswa terhadap prestasi belajar siswa: nilai $\mathrm{F}$ hitung $=0,843$ dengan probabilitas $(p)=$ 0,363 . Oleh karena $\mathrm{p}>0,05$; maka Ho diterima, atau interaksi antara metode pembelajaran dengan berpikir kritis tidak memberikan pengaruh signifikan terhadap prestasi belajar. Hal ini disebabkan a) karena dalam pembelajaranya baik memakai metode eskperimen atau diskusi anak terlibat langsung dengan kegiatan yang dipandu dengan lembar kerja siswa dan dibimbing oleh guru, sehingga anak yang mempunyai sikap berpikir kritis tinggi atau rendah sama-sama aktif. Sehingga tidak dapat mempengaruhi prestasi belajar. b) Banyak faktor yang mempengaruhi proses pencapaian prestasi belajar, mungkin disebabkan faktor dari dalam diri siswa diluar metode pembelajaran dan berpikir kritis.

Teori pendukung proses pembelajaran yang dikembangkan oleh Kembar dalam (Sudaryanto, 2008: 65) 
kurangnya pemahaman pendidik tentang berpikir kritis menyebabkan adanya kecenderungan untuk tidak mengajarkan keterampilan berpikir kritis pada siswa, sedangkan di dalam kurikulum siswa dituntunt untuk dapat mengembangkan kemampuan berpikir kritis. Siswa dengan kemampuan berpikir kritis tinggi tentunya lebih mudah dalam penggabungan informasi dan gagasan baru ke dalam satu sudut pandang, konsep dan asumsi yang dimiliki. Siswa akan dapat menafsirkan data dan menyimpulkan informasi yang diperoleh.

Pada saat pembelajaran berlangsung, siswa tampak belum terbiasa belajar secara mandiri dan belum sepenuhnya aktif dalam kegiatan pembelajaran. Hal ini dimungkinkan karena siswa masih beradaptasi dengan model pembelajaran yang baru mereka kenal, hanya sebagian kecil siswa yang berusaha mengembangkan kemampuan berpikir kritis yang mereka miliki. Oleh karena itu, dalam melaksanakan pembelajaran guru harus mulai mengenal model pembelajaran yang dapat mengasah kemampuan berpikir kritis, karena kemampuan tersebut merupakan salah satu faktor internal siswa yang penting dalam pemrosesan informasi pengetahuan yang akan mereka dapatkan. Menurut Menurut Sam Aun Vong dan Wareerat Kaewurai (2017: 94) Instruksi yang tepat sangat berhasil dalam melatih pemikiran kritis siswa dan mengembangkan kemampuan mereka dalam mengajarkan pemikiran kritis. Untuk menanamkan siswa peserta pelatihan dengan kemampuan berpikir kritis dan kemampuan berpikir kritis mengajar adalah menganggapnya bukan sebagai penerima informasi, namun sebagai pengguna informasi. Selanjutnya, menurut Thomas E. Hunt (2017: 96) The Critical Thinking Toolkit (CriTT) mengukur keyakinan dan sikap tentang pemikiran kritis. Ini terdiri dari tiga faktor, yang berkorelasi dengan aspek pemikiran kritis dan teoritis, dan merupakan prediksi kinerja akademis. Faktor pertama, 'Keyakinan Berpikir Kritis', mengukur kepercayaan peserta pada pemikiran kritis. Yang kedua, 'Valuing Critical Thinking', mengukur sejauh mana siswa menyadari pentingnya berpikir kritis. Faktor ketiga, 'Kesalahpahaman', mengukur penghindaran pemikiran kritis atau kesalahpahaman pemikiran kritis.

5. Hipotesis Kelima

Berdasarkan penjabaran pada diskripsi statistik uji interaksi metode pembelajaran dengan kreativitas siswa: Pada tabel uji interaksi pengaruh metode pembelajaran dan kreativitas siswa terhadap prestasi belajar siswa: nilai $\mathrm{F}$ hitung $=4,124$ dengan probabilitas $(\mathrm{p})=$ 0,047 . Oleh karena $\mathrm{p}<0,05$; maka Ho ditolak, atau interaksi antara metode pembelajaran dengan kreativitas siswa memberikan pengaruh signifikan karena dalam pembelajaranya baik memakai metode eksperimen atau diskusi pembelajarannya dibagi menjadi beberapa kelompok sehingga setiap anak dapat terlibat secara langsung.

Berdasarkan rata-rata prestasi belajar diperoleh bahwa peserta didik dengan kreativitas tinggi juga menghasilkan hasil belajar yang lebih baik jika diberi pembelajaran melalui pendekatan penemuan. Menurut Adzliana Mohd Daud, Jizah Omar, Punia Turiman \& Kamisah Osman (2011: 142) Strategi pengajaran kreatif dapat membantu siswa menghasilkan ide baru dan menjelajahi daerah secara lebih mendalam. Selain itu, dengan teknik yang tepat dalam mengembangkan ide kreatif, siswa dapat mengembangkan bakat yang ada dan selalu memikirkan cara terbaik untuk mengembangkan bakat dan kemampuan. Selain itu, menurut Konstantinidou, E (2015: 28) Sebagai kesimpulan, temuan dari penelitian ini menunjukkan bahwa salah satu penghambat utama kreativitas yang mendorong lingkungan kelas adalah lingkungan dan sumber daya pendidikan dan khususnya terjemahan kebijakan yang bermasalah dalam praktik. 


\section{Hipotesis Keenam}

Berdasarkan penjabaran pada diskripsi statistik uji interaksi berpikir kritis dengan kreativitas siswa : Pada tabel uji interaksi pengaruh berpikir kritis dan kreativitas siswa terhadap prestasi belajar siswa: nilai $\mathrm{F}$ hitung $=0,241$ dengan probabilitas $(\mathrm{p})=0,625$. Oleh karena $\mathrm{p}>$ 0,05; maka Ho diterima, atau interaksi antara berpikir kritis dan kreativitas siswa tidak memberikan pengaruh signifikan terhadap prestasi belajar.

Kreativitas dengan kemampuan berfikir kirtis secara teori dapat dikembangakan atau ditingkatkan dengan metode demonstrasi dan eksperimen. Pada penelitian ini pelaksanaan pembelajaran demonstrasi, dan eksperimen kurang maksimal. Diskusi hasilnya kurang lancar, dikarenakan pembagian kelompok yang kurang merata sehingga hasil tes prestasi lebih menunjukan pada kemampuan masing-masing bukan kemampuan dari hasil metode demonstrasi, dan eksperimen. Sehingga antara kreativitas dengan kemampuan berfikir kirtis tidak ada interaksi. Menurut Patricia Gutiérrez Rivas (2017: 171) Namun, di atas semua manfaat yang terlibat dalam proyek ini, siswa memiliki kesempatan untuk memperkuat dan mengembangkan keterampilan intelektual yang terkait dengan perolehan pemikiran kritis dan kreatif serta untuk saling mengaitkan pekerjaan mereka dengan area lain. Pengetahuan. Selanjutnya, menurut Ali Salim Rashid Alghafri dan Hairul Nizam Bin Ismail (2014: 524) Penelitian ini telah berkontribusi untuk mengintegrasikan pemikiran kreatif dengan pemikiran kritis. Mereka berhasil mendukung pemikiran dan pembelajaran siswa primer dengan melibatkan keterampilan berpikir dalam strategi pembelajaran. Ini dibuat agar sesuai untuk semua tingkat siswa.

7. Hipotesis Ketujuh

Berdasarkan penjabaran pada diskripsi statistik uji interaksi metode pembelajaran, berpikir kritis dan kreativitas siswa: Pada tabel uji interaksi metode pembelajaran, berpikir kritis dan kreativitas siswa: nilai $\mathrm{F}$ hitung $=4,129$ dengan probabilitas $(p)=0,047$ Oleh karena $\mathrm{p}<0,05$; maka Ho ditolak, atau interaksi metode pembelajaran, berpikir kritis dan kreativitas siswa memberikan pengaruh signifikan terhadap Prestasi Belajar: 1) Karena dalam pembelajaranya baik memakai metode eksperimen atau diskusi pembelajaranya dibagi menjadi beberapa kelompok sehingga setiap anak dapat terlibat langsung; 2) Dalam membuat kesimpulan dilakukan diskusi kelompok baik metode eksperimen maupun metode diskusi, siswa yang mempunyai sikap berpikir kritis semuanya ikut terlibat dalam mengambil kesimpulan; 3) Materi mudah diaplikasikan dalam kehidupan sehari hari; 4) Disebabkan faktor dari dalam diri siswa (internal maupun eksternal).

Ditinjau dari nilai rata-rata prestasi belajar kognitif, diketahui bahwa peserta didik dengan kemampuan berpikir kritis tinggi dan kreativitas tinggi memberikan hasil yang lebih baik dibandingkan yang lainnya. Sehingga lebih cocok menggunakan metode eksperimen sebagai sarana untuk meningkatkan prestasi belajar kognitif peserta didik. Peserta didik yang memiliki kemampuan berpikir kritis rendah dan kreativitas rendah dengan metode eksperimen memberikan hasil yang lebih baik dibandingkan dengan peserta didik yang diberikan metode demonstrasi, sehingga peserta didik dengan kemampuan berpikir kritis rendah dan kreativitas rendah lebih cocok diberikan metode eksperimen untuk meningkatkan prestasi belajar. Sementara peserta didik dengan kemampuan berpikir kritis dan kreativitas dengan tingkatan lain leboh cocok menggunakan metode demonstrasi. Peserta didik dengan kreativitas dan kemampuan berpikir kritis tinggi memiliki kemampuan berpikir yang lebih baik sehingga dapat menemukan dan menyelesaikan masalah dalam memahami konsep. 
Peserta didik dengan kemampuan berpikir kritis tinggi berperan penting pada pembelajaran yang melibatkan kelompok belajar, terutama dalam kegiatan diskusi kelompok karena dapat memberikan konstribusi pemikiran yang dimilikinya kepada teman sekelompoknya. Demikian pada peserta didik dengan kreativitas tinggi mampu melahirkan ide atau penemuan baru, aktif dalam proses pembelajaran serta mampu mempertahankan ide-ide baru yang ditemukan sehingga peserta didik mampu memahami konsep pembelajaran dengan penemuan masalah serta menyelesaikannya secara sederhana. Hal ini sesuai dengan penelitian yang menyatakan bahwa penggunaan metode eksperimen dan demonstrasi memberikan pengaruh terhadap peningkatan prestasi belajar (Sihana, 2010). Menurut Slaÿana Živkoviü (2016: 107) Kelas abad ke-21 membutuhkan siswa untuk menghadapi masalah di dunia nyata yang melibatkan mereka dalam kemampuan berpikir tingkat tinggi kreativitas, inovasi, komunikasi, kolaborasi, pemikiran kritis dan pemecahan masalah. Berpendapat Harus ditunjukkan bahwa institusi pendidikan terlalu sering menekankan hafalan. Selain itu, menurut Phil Clegg (2018: 219) akademisi kritis yang ingin mempromosikan kreativitas di antara siswa harus hidup dalam kerangka kerja ambiguitas permanen, di satu sisi, dikelilingi oleh kebingungan ideologi yang saling bertentangan (ditambah faktor pembatas lainnya). Hal inilah yang menyebabkan sehingga berpikir kritis, kreativitas siswa dan metode mengajar ada interaksi.

\section{Kesimpulan dan Rekomendasi}

\section{Simpulan}

1. Ada perbedaan hasil belajar fisika terhadap penggunaan metode eksperimen dan metode demonstrasi. Dari hasil analisis data diperoleh signifikan $0,025<$ 0,05 maka metode pembelajaran memberikan perbedaan yang signifikan terhadap hasil belajar atau ada perbedaan hasil belajar antara metode eksperimen dan metode demonstrasi. Menurut rerata dari hasil analisis menunjukkan bahwa pembelajaran dengan metode eksperimen $(87,60)$ lebih unggul dari pada metode demonstrasi $(83,73)$.

2. Ada perbedaan hasil belajar terhadap kemampuan berpikir kritis tinggi dan kemampuan berpikir kritis rendah. Dari hasil analisis data diperoleh signifikan $0,000<0,05$ yang berarti bahwa kemampuan berpikir kritis memberikan perbedaan yang signifikan terhadap hasil belajar atau ada perbedaan hasil belajar terhadap kemampuan berfikir kritis tinggi dan kemampuan berfikir kritis rendah. Menurut rerata dari hasil analisis menunjukan bahwa kemampuan berfikir kritis tinggi $(90,62)$ lebih unggul dari pada kemampuan berfikir kritis rendah $(81,03)$.

3. Ada perbedaan hasil belajar terhadap kreativitas tinggi dan kreativitas rendah. Dari hasil analisis data diperoleh signifikan $0,030<0,05$ yang berarti bahwa kreativitas memberikan perbedaan yang signifikan terhadap hasil belajar atau ada perbedaan hasil belajar terhadap kreativitas tinggi dan kreativitas rendah. Menurut rerata dari hasil analisis menunjukan bahwa kreativitas tinggi $(88,83)$ lebih unggul dari pada kreativitas rendah $(83,56)$.

4. Tidak ada interaksi antara metode pembelajaran dengan cara berpikir kritis siswa. Dari hasil analisis data diperoleh signifikan $0,363>0,05$ yang berarti metode pembelajaran dan cara berpikir kritis siswa secara bersama-sama tidaklah memberikan hasil yang signifikan terhadap prestasi belajar atau dengan kata lain rata-rata prestasi belajar siswa dari kelompok metode eksperimen selalu lebih tinggi dari kelompok metode diskusi baik untuk cara berpikir kritis siswa tinggi maupun rendah.

5. Ada interaksi antara metode pembelajaran dengan kreativitas siswa. Dari hasil analisis data diperoleh signifikan $0,047<$ 0,05 yang berarti bahwa metode pembelajaran dan kreativitas siswa secara bersama-sama memberikan hasil yang signifikan terhadap prestasi belajar siswa. 
6. Tidak ada interaksi antara cara berpikir kritis siswa dengan kreativitas siswa. Dari hasil analisis data diperoleh nilai signifikan 0,625 > 0,05 yang berarti cara berpikir kritis siswa dan kreativitas siswa secara bersama-sama tidaklah memberikan hasil yang signifikan terhadap prestasi belajar atau dengan kata lain rata-rata prestasi belajar siswa dari kelompok cara berpikir kritis selalu lebih tinggi dari kelompok cara berpikir kritis rendah baik untuk kreativitas siswa tinggi maupun rendah.

7. Ada interaksi antara metode pembelajaran, cara berpikir kritis siswa, dan kreativitas siswa. Dari hasil analisis data diperoleh nilai signifikan 0,047 < 0,05 yang berarti metode pembelajaran, cara berpikir kritis siswa, dan kreativitas siswa secara bersama-sama memberikan hasil yang signifikan terhadap prestasi belajar siswa atau dengan kata lain ratarata prestasi belajar siswa dari kelompok metode eksperimen lebih baik daripada kelompok metode diskusi baik untuk cara berpikir kritis tinggi maupun rendah juga kreativitas tinggi siswa maupun kreativitas rendah siswa.

\section{Saran}

Berdasarkan kesimpulan diatas, peneliti menyarankan beberapa hal yang perlu diperhatikan:

1. Pembelajaran metode eksperimen baik untuk sekolah tinggi, sedang, rendah dapat mengembangkan kemampuan berpikir kritis dan kemampuan kreatif siswa. Oleh karena itu hendaknya pembelajaran ini terus dikembangkan dilapangan dan dapat dijadikan sebagai slah satu alternatif pilihan guru dalam menentukan metode pembelajaran fisika yang membuat siswa aktif secara mental dan termotivasi untuk belajar. Selain itu, guru hendaknya tetap memperhatikan pengetahuan awal yang dimiliki siswa sehingga metode pembelajaran dapat mencapai hasil yang maksimal.

2. Agar dapat mengimplementasikan metode pembelajaran di kelas, guru perlu mempersiapkan bahan ajar yang cocok serta membuat antisipasi dari respon yang mungkin muncul dari siswa. Sehingga guru dapat memberikan scaffolding yang tepat untuk siswa sehingga merangsang siswa untuk melakukan eksplorasi dan penyelidikan dalam memperoleh pengetahuan baru yang lebih bermakna.

3. Bagi peneliti selanjutnya, apabila ingin mengembangkan berpikir kritis juga kreativitas siswa perlu digali secara lebih mendalam kemampuan siswa pada masing-masing indikator berdasarkan peringkat sekolah, pengetahuan awal fisika siswa secara keseluruhan. Ditambahkan vidio pada setiap praktikum agar supaya siswa lebih mudah memahami materi. Materi pokok dimunculkan dengan metode penemuan pada bab II.

\section{Daftar Pustaka}

Abdelrahman Kamel Abdelrahman Mahmoud. 2014. The Effect of Using Discovery Learning Strategy in Teaching Grammatical Rules to first year General Secondary Student on Developing Their Achievement and Metacognitive Skills. Faculty of Education, Fayoum University, Egypt

Adzliana Mohd Daud. 2011. Creativity in Science Education. Faculty of Education, Universiti Kebangsaan Malaysia

Ali Salim Rashid Alghafri and Hairul Nizam Bin Ismail. 2014. The Effects of Integrating Creative and Critical Thinking on Schools Students' Thinking. Ministry of Education, Sultanate of Oman

Aunurrahman. 2009.Belajar dan Pembelajaran. Bandung: Alfabeta

Budiyono. 2004. Statistika Untuk Penelitian. Surakarta: Sebelas Maret University Press.

Burney, A. 2008. Induktive and Deductive Resech Approach. Karachi: Departement of Computer Science, University of Karachi

Dewi Salma Prawidilaga. 2008.Prinsip Disain Pembelajaran. Jakarta: Kencana Predana Media Grup 
Edward J.N. 2017. Development of the Critical Thinking Toolkit (CriTT): Ameasure of student attitudes and beliefs about critical thinking. Psychology Department, University ofDerby, United Kingdom.

Frederick A. Ricci. Cultivating Critical Thinking Within Organizations. Nova Southeastern University, THE UNITED STATES . 2014

Hamalik, Oemar. 2005. Kurikulum Dan Pembelajaran. Bima Aksara

Imam Taufik. 2010.Kamus Praktis Bahasa Indonesia. Jakarta: Ganeca

Konstantinidou, E. 2015. Barriers and Inhibitors of Creativity in Physical Education. School of Physical Education \& Sport Science, Democritus University of Thrace, Greece

Mohammad Asrori. 2007. Psikologi pembelajaran. Bandung: Wacana Prima

Monireh Eskandari . 2016. The Effect of Collaborative Discovery Learning Using MOODLE on the Learning of Conditional Sentences by Iranian EFL Learners. Department of English, College of Humanities, Qom Branch, Islamic Azad University, Qom, Iran

Mustaqim Abdul Wahid. 2010.Psikologi Pendidikan. Jakarta: Aji Mahasatya

Nana Syaodih Sukmadinata. 2009 . Landasan Psikologi Proses Pendidikan. Bandung: Remaja Rostakarya.

Patricia Gutiérrez Rivas. 2017. Strategies for teaching and dissemination of artistic heritage by promoting critical and creative thinking among future Primary Education teachers. Research Group Studia Humanitates, Universidad Católica de Murcia, EspañaPaul Suparno. 2007. Metodologi Pembelajaran Fisika Kontruktivis Dan Menyenangkan. Yogyakarta: universitas sanata darma

Phil Clegg 2018. Creativity and critical thinking in the globalised university. Faculty Of Health Leeds Metropolitan University Leeds, UK Qonita Alya. 2009.Kamus Praktis Bahasa Indonesia. Jakarta: Ganeca

Santrock..2008.Psikologi Pendidikan. Jakarta: Kencana Predana Media Group
Šarka Janků, and Petrŕková Růžena,. 2015. The using of innovation and creativity is inexhaustible. VSP Ostrava, Michálkovická 1810/181,710 00 Slezská Ostrava

Slameto. 2010.Belajar dan Faktor-Faktor yang Mempengaruhi. Jakarta: Rineka Cipta

Slaÿana Živkoviü . 2016. A Model of Critical Thinking as an Important Attribute for Success in the 21st Century. College of Applied Technical Sciences \& Faculty of Civil Engineering and Architecture, Aleksandra Medvedeva 20, 18000, Niš, Serbia

Suparno, P. 2007. Metodologi Pembelajaran Fisika. Yogyakarta: Universitas Sanata Dharma

Sudaryanto. 2008. Kemampuan Berpikir Kritis. Bandung: Remaja Rosdakarya

Sudjana, N. 2009. Penelitian Dan Penilaian Pendidikan. Bandung: PT Remaja Rosdakarya.

Suharsimi Arikunto,. 2007. Dasar-dasar Evaluasi Pendidikan. Jakarta: Bumi Aksara

Sugiyono. 2008. Metode Penelitian Pendidikan.Bandung : Alfabeta

Syaiful Sagala. 2009. Konsep Dan Makna Pembelajaran. Bandung: alfabeta

Theresa Jones. 2017. Playing Detective to Enhance Critical Thinking. Fairmont State University, Fairmont, WV

Tri Cahyono, 2006. Statistik Uji Normalitas. Semarang:Politeknik Kesehatan Depkes Semarang

Trianto. 2010. Mendesain Model Pembelajaran Inovatif-Progresif. Jakarta: Prestasi Pustaka Publisher

Wareerat Kaewurai 2017. Instructional mo del develop ment to enhance critical thinking and critical thinking teaching ability of train students at region al teaching train ing center in Takeo province, Cambodia. Department of Education, Faculty of Education, Naresuan University, Phitsanulok 65000, Thailand

Winkel. 2007. Pesikologi Pengajaran. Yogyakarta: Media Abadi 
JURNAL INKUIRI

ISSN: 2252-7893, Vol. 7, No. 1, 2018 (hal 13-28)

http://jurnal.uns.ac.id/inkuiri 